EUI Working Paper RSC No. 96/3

State Power

and Institutional Influence in European Integration

Lessons from the Packaging Waste Directive

\title{
JONATHAN GOLUB
}

\section{EUI WORKING PAPERS}

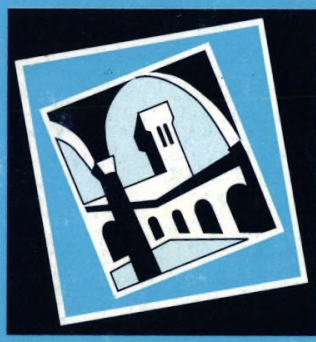


EUROPEAN UNIVERSITY INSTITUTE

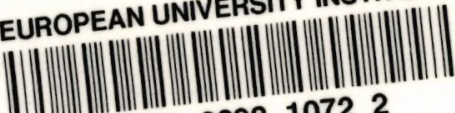

30001002310722 


\section{EUROPEAN UNIVERSITY INSTITUTE, FLORENCE \\ ROBERT SCHUMAN CENTRE}

State Power and Institutional Influence in European Integration:

Lessons from the Packaging Waste Directive JONATHAN GOLUB

EUI Working Paper RSC No. 96/3 
All rights reserved.

No part of this paper may be reproduced in any form without permission of the author.

(C) Jonathan Golub

Printed in Italy in February 1996

European University Institute

Badia Fiesolana

I - 50016 San Domenico (FI)

Italy 


\begin{abstract}
${ }^{1}$
This study traces the development of the recently adopted packaging waste directive in order to illuminate the role of various actors in the integration process. While some of the findings about agenda-setting and qualified majority voting presented in this study apply directly to the sector of environmental policy, or specifically to the chosen case, the broader conclusions suggest the need for additional case studies of EC legislation and offer a theoretical framework in which these studies may be used to test competing notions of European integration. To this end, the study uses lessons from the case of packaging waste to refine the ongoing debate between scholars who propose state-centric models and those who advocate a view of Europe in which power is diffused to supranational institutions at the expense of state sovereignty.
\end{abstract}

${ }^{1}$ A revised version of this paper is forthcoming in Journal of Common Market Studies 34 (3), September 1996. 


\section{Introduction}

After nearly three years of protracted negotiations between the institutions of the European Community, the Council of Ministers formally adopted Directive 94/62/EC on packaging and packaging waste in December 1994 (OJL365 31.12.94). This study traces the development of the directive in order to illuminate the role of various actors in shaping EC environmental policy. As the first major example of EC environmental policymaking under the Maastricht Treaty, and having become the most heavily lobbied dossier in the history of the European institutions the packaging directive provides the perfect vehicle through which to assess a number of larger questions surrounding European integration.

The directive exemplifies the conflict between the Community's attempt to achieve free trade amongst member states and its central environmental policy objectives--preventing pollution at the source and achieving sustainable development. As such, one would expect that the lessons learned from the development of the packaging directive would be applicable to the study of a wide range of other Community actions in the field of environmental protection.

More importantly, however, insight into the actual interplay between the Council, Commission, European Parliament allows tentative conclusions to be drawn about the character of the integration process: the ability of the Commission to set and retain control of the agenda, the impact of the European Parliament on the content of directives, and the extent to which qualified majority voting produces Council decisions which are at a level above the lowest-common denominator. Ultimately, by tracing the directive through its many versions, assessing the role of various actors and thereby identifying "winners" and "losers", this study seeks to contribute to the larger debate about whether EC integration strengthens the state, or rather empowers supranational institutions at the expense of national sovereignty. 
The question inevitably arises as to how generalisable are conclusions based on a single case study and how representative is the chosen study of overall Community policymaking. No claim is made here that an analysis of the packaging waste directive captures all types of decisionmaking within the Community, nor that all Community legislation develops in a similar manner. Instead, it is suggested that the packaging waste example raises a number of important questions about state power and institutional influence which are germane to the large segment of EC decisionmaking which involves positive integration and the harmonisation of diverging national regulations. While some of the findings presented in this study apply directly to the chosen case, the broader conclusions suggest the need for additional case studies of EC legislation and offer a theoretical framework in which these studies may be used to test competing notions of European integration.

The paper proceeds as follows. The first section traces the development of the packaging directive throughout the entire policymaking cycle--pre-draft stage, official Commission proposal, first reading in the European Parliament, common position in the Council, second reading in the European Parliament, adoption by Council. A primary aim of the first section is to identify the key legislative objectives of the Commission and Parliament, as well as to provide a picture of the current and projected recycling plans of the member states.

The second section examines in more detail the role of each institutional actor. Evidence of how the packaging directive actually developed is used to test a variety of predictions about the role of each institution in the decisionmaking procedure which stem from the available theoretical and empirical literature. This section uses experience from the case of packaging to test notions of agenda-setting, parliamentary influence, and intra-Council bargaining.

The third section uses the packaging case to address broader questions of European integration. It seeks to refine the current debate between scholars 
who propose state-centric models and those who advocate a view of Europe in which power is diffused at the expense of state sovereignty. This section draws heavily on two recent analyses by Andrew Moravcsik and Gary Marks which have come to frame the debate between these two competing concepts of European integration (Moravcsik 1994, Marks 1994). The case study of the packaging directive reveals that this debate has a tendency to proceed along effectively unrelated paths, with state centrist models focusing on the issue of power while diffusion theorists concentrate instead on the issue of influence. It is suggested that a clearer distinction between these two issues demonstrates the strengths as well as the shortcomings of each theory, and provides a useful analytical framework in which to place future empirical studies.

\section{The Problem Of Packaging Waste In The EC}

Disposing of the nearly 50 million tonnes of packaging waste produced each year and the "waste mountains" which already exist throughout the Community presents member states with serious environmental and economic problems. Some member states have introduced voluntary or compulsory agreements with industry to reduce the production of packaging waste, encourage its reuse or recycling. The most ambitious programmes have been implemented by Denmark, Germany and the Netherlands. Before reuse or recycling can occur however, packaging waste must be "recovered", which entails collecting and sorting various materials from the general waste stream. In some cases states require the recovery of most, if not all packaging waste. This presents a number of disposal problems. Burning or burying such enormous quantities of waste places human health at risk. Recycling of waste may prevent damage to the environment and to health but only after a substantial investment in appropriate technology. Faced with the costs of recycling and the inability to dispose of waste safely within their own borders, 
some states pay to incinerate, landfill or recycle their used packaging in other EC countries.

Swamped with what are effectively subsidised waste imports, and thus unable to dispose effectively of their own packaging, several member states began conisering plans to restrict landfill, incineration and recycling to domestic waste only (House of Lords 1993). While this might solve the problems of a few states, it would of course result in even higher waste mountains in countries which relied on exporting used packaging.

Equally important, restrictions on waste imports raised serious questions about the free movement of goods throughout the Community. Although the ECJ has upheld the right of an individual country under Article 36 to enact environmental laws more stringent than those found in other member states, such exceptions to Article 30 are allowed only under certain circumstances-the national measures must be necessary to improve protection of the environment, and they must not discriminate between foreign and domestic producers. ${ }^{2}$ Although its most recent ruling on the matter contains contradictory statements about how to balance environmental protection and free movement of goods, the Court appeared willing to allow bans on specific waste imports destined for landfill (von Wilmowsky 1993).

Nevertheless, there are several reasons to believe that the Court would not allow similar specific bans, let alone general bans, of transnational waste shipments destined for recycling. First, contrary to the Treaty, such bans necessitate a clear discrimination between domestic and foreign producers. Even Ludwig Krämer, an EC lawyer sympathetic to unilateral national environmental actions, agrees that "any import restriction on waste constitutes

\footnotetext{
${ }^{2} \mathrm{~A}$ full review of the case law relating to Article 30 and Article 36 has been made elsewhere, and is not necessary for the present discussion. See Case 302/86, Commission v. Denmark [1988] ECR 4607; Case 2/90, Commission v. Belgium [1992]; Sexton (1991), Krämer (1993), von Wilmowsky (1993).
} 
an arbitrary discrimination and is therefore incompatible with Article 30" (Krämer 1993:128-9).

Second, unlike bottle recycling laws or regulations obliging the use of biodegradable plastic bags, bans on waste destined for recycling do nothing to improve the overall quality of the environment, as pollution is merely relocated rather than reduced. The Court has often held that it makes no difference from an ecological point of view which state disposes of waste, as long as disposal occurs. In sum, the existing case law suggests that the ECJ would not tolerate national bans on imported packaging waste because they constitute unjustified barriers to trade (von Wilmowsky 1993:558). In other words, Community law did not require states to develop self-sufficient means of recycling their packaging waste but could instead make use of recycling facilities in neighbouring states.

In order to avert protracted legal proceedings over the legitimacy of "green protectionism" and to reduce the environmental threats from excessive packaging waste in the Community, the Commission began considering various preventive and harmonising measures. The Commission's efforts culminated in its proposal on packaging and packaging waste in July 1992, which was made under Article 100A of the Treaty.

\section{The Policymaking Cycle}

From Pre-draft to Draft: the Commission Abandons its Bold Objectives

The driving force behind the proposal was to prevent "green protectionism" from destroying the free movement of packaging waste within the Community without also preventing member states from finding ways to deal effectively with their own waste. These two objectives are not easily reconciled--one way of dealing with national waste is to export it to neighbouring states for disposal, often at heavily subsidised rates, a practice which undermine the capacity of the receiving state to deal with its own 
problems of packaging waste. Hence the rise of protectionism to keep out enormous subsidised waste shipments, particularly from those arising from the German Duales System Deutschland (DSD) scheme which was introduced in 1991 by environment minister Klaus Töpfer. ${ }^{3}$

In order to maintain free movement of goods without condemning some states to act as disposal havens and to suffer burgeoning waste mountains, and in line with its emphasis on preventing environmental damage at the source, the Commission originally sought to introduce three major elements into its proposal: 4

1) Freezing the Community's output of waste at current levels by setting a per capita maximum of $150 \mathrm{~kg} / \mathrm{yr}$ of packaging waste, to be achieved within ten years.

2) Targets: A mandatory minimum "recovery" rate of $60 \%$ (by weight) for all packaging waste within five years, rising to $90 \%$ after ten years. ${ }^{5}$ A mandatory minimum recycling rate of $40 \%$ (by weight) for each type of packaging material within five years; rising to $60 \%$ after ten years. 6 Minimisation of the final disposal of packaging waste (i.e.-by landfill or incineration without energy recovery) to no more than $10 \%$ by weight of packaging waste output after ten years. Thus, after ten years, $60 \%$ of packaging waste would have to be recycled, $30 \%$ could be recovered but not recycled, and no more than $10 \%$ could be disposed of through rubbish tips or incineration without energy recovery.

3) Hierarchy of Disposal Options: The Commission originally wanted to encourage what it considered to be the most ecologically rational disposal methods by including within the proposal a hierarchy of goals: prevention, re-use, recycling, incineration with energy recovery, incineration without energy recovery, landfill.

\footnotetext{
${ }^{3}$ See Financial Times, 6 December 1991; Economist, 29 May 1993; House of Lords (1993); Agence Europe, 5/6 July 1993.

${ }^{4}$ These elements featured in the seven pre-draft versions of the proposal which were under negotiation within the Commission since 1990.

5Recovery includes, among other things listed in Annex IIB of the framework directive $75 / 442$ on waste: re-use, recycling, composting, regeneration, and recovery of energy.

${ }^{6}$ Recycling includes re-use, composting and regeneration.
} 
As originally conceived, the Commission's targets exceeded the existing plans of many EC countries and were modelled to a large extent on the ambitious national recycling achievements and goals of Germany and the Netherlands. The following two tables show recycling rates within the Community for each type of packaging material and the commitment of each member state to increase recovery and recycling in the coming years. ${ }^{7}$ Calculation of plastic recycling rates is particularly problematic and is discussed in greater detail later in this paper.

Table 1 National Recycling Rates

\begin{tabular}{|l|l|l|l|}
\hline & $\begin{array}{l}\text { Paper and board } \\
(1990)\end{array}$ & $\begin{array}{l}\text { Aluminium } \\
(1987)\end{array}$ & $\begin{array}{l}\text { Glass } \\
(1993)\end{array}$ \\
\hline Germany & 40 & 31 & 65 \\
\hline Denmark & 35 & 31 & 64 \\
\hline Netherlands & 50 & 47 & 76 \\
\hline Belgium & $36(1988)$ & $4(1987)$ & 55 \\
\hline France & 46 & 25 & 46 \\
\hline UK & 31 & 19 & 29 \\
\hline Luxembourg & NA & NA & NA \\
\hline Italy & 25 & 36 & 52 \\
\hline Spain & 51 & 28 & 29 \\
\hline Greece & 21 & $25(1990)$ & 27 \\
\hline Portugal & 39 & 4 & 29 \\
\hline Ireland & 3 & NA & 29 \\
\hline
\end{tabular}

${ }^{7}$ Source: compiled from European Environment, 28 July 1992; Newman and Foster (1993); UNEP (1991,1992,1994); van Goethem (1993). 
Table 2 Commission Proposal Compared with National Plans

\begin{tabular}{|c|c|c|}
\hline & Recovery Targets & Recycling Targets \\
\hline $\begin{array}{l}\text { Commission } \\
\text { Proposal }\end{array}$ & $\begin{array}{l}\text { 2000: } 60 \% \text { of all materials } \\
\text { 2005: } 90 \% \text { of all materials }\end{array}$ & $\begin{array}{l}\text { 2000: } 40 \% \text { of each material } \\
\text { 2005: } 60 \% \text { of each material }\end{array}$ \\
\hline Germany & 1995: $80 \%$ of each material & 1995: $64-72 \%$ of each material \\
\hline Denmark & NA & 2000: $50 \%$ of each material \\
\hline Netherlands & 2000: $90 \%$ of each material & 2000: $50-80 \%$ of each material \\
\hline $\begin{array}{l}\text { Belgium } \\
\text {--Flanders } \\
\text {--Wallonia }\end{array}$ & $\begin{array}{l}\text { 2000: } 58 \% \text { of all materials } \\
\text { 2000: } 60-80 \% \text { of all materials }\end{array}$ & 1998: $70-80 \%$ of each material \\
\hline France & 2002: $75 \%$ of all materials & 2000: $75 \%$ of glass \\
\hline$\overline{\mathrm{UK}}$ & $2000: 50-75 \%$ of all material & \\
\hline Luxembourg & 1995: $95 \%$ of liquid food containers & 1994: $78 \%$ of liquid food containers \\
\hline Italy & NA & $\begin{array}{l}\text { 1993: } 40-50 \% \text { for each type of liquid } \\
\text { container }\end{array}$ \\
\hline Spain & NA & NA \\
\hline Greece & NA & NA \\
\hline Portugal & NA & $\overline{\mathrm{NA}}$ \\
\hline Ireland & NA & $\overline{\mathrm{NA}}$ \\
\hline
\end{tabular}

For most member states the original Commission proposal would have entailed a serious reconsideration of strategies aimed at reducing and recovering certain types of packaging waste. In a few cases it might also have involved additional investment in recycling technology. For the less developed and southern states the Commission proposal would have required a complete overhaul of their waste management programs, forcing the introduction of set recycling targets and implementation deadlines, each of which were practically unheard of or limited to individual types of waste such as drink containers.

The Commission immediately came under pressure from the member states and from industrial groups to make the proposal more flexible. Some states, mainly Germany, Denmark and the Netherlands wanted either higher Community targets or flexibility which guaranteed that the directive would not prevent them from adopting more stringent standards of their own. Other states worried that the targets were already too high and impossible to meet. The Bureau International de la Récupération, the Association of Plastics 
Manufacturers of Europe, the European Organisation for Packaging and the Environment, the European Recovery and Recycling Association, the Alliance for Beverage Cartons, along with several other large European peak organisations for packaging and recycling feared that overly-ambitious recovery and recycling targets failed to take account of the market for these products. 8

In response to this pressure the Commission abandoned many of its original goals by the time it released the first official draft. ${ }^{9}$ Gone were the per capita waste provision, the binding intermediary five year targets and the hierarchy of disposal methods. What remained was a 90 percent recovery target and a 60 percent recycling target over ten years, with states required to predict when they would meet the intermediary targets.

\section{The European Parliament's First Reading}

Under the terms of the co-decision procedure the European Parliament (EP) has two opportunities to amend the packaging proposal. Each "reading" is actually a two-part process: first, the Environment Committee of the EP issues a report suggesting amendments; second, this report is adopted in part or in full by the rest of the EP.

In its report, the Environment Committee put forward 79 amendments. True to its reputation as a source of zealous environmental concern, it proceeded to reintroduce most of the provisions originally favoured by the Commission, including the hierarchy of disposal methods and the binding five year recovery and recycling targets. The Committee also sought to guarantee the rights of individual member states to opt-up for more stringent domestic standards, balancing admonitions against distorting the market with language

\footnotetext{
${ }^{8}$ Industry and trade representatives set up two highly successful pressure groups: the packaged consumer goods industries coordination group, and the packaging legislation ad hoc group. See Club de Bruxelles (1994).

${ }^{9} \mathrm{OJ}$ C263 12.10.92. See Europe Environment, 4 February 1992, 28 July 1992 and 1 December 1992; Agence Europe, 16 July 1992 and 18 July 1992.
} 
clearly designed to allow ambitious national economic instruments such and waste exports (European Parliament 1993).10 These amendments suggested that because no exact had been given of what constituted a high level of environmental protection, member states could take "more rigorous" unilateral measures as long as the goal was to protect the environment. The Environment Committee also sought to require mandatory minimum proportions of recycled material in packaging, to eliminate in ten years all packaging containing certain heavy metals, and to take account of the special conditions affecting islands. ${ }^{11}$ This latter concern, although extremely ambiguous, was the first sign that the EC might consider derogations for some regions.

On 23 June 1993 the EP accepted most of the Environment Committee's major recommendations, retaining the hierarchy, the intermediary standards, the minimum content of recycled materials in packaging, the sensitivity to the needs of islands. However, while the EP expanded the scope of unilateral national action slightly by accepting the amendments allowing national economic instruments which pursued environmental goals, it rejected all three amendments aimed at allowing broad national opt-ups. It also rejected the mandatory ban on packaging containing heavy metals. ${ }^{12}$

\section{Round Two}

Still wanting to maximise the green provisions of the directive but aware of the Council's concerns about flexibility and having received the results of the EP's first reading, the Commission produced an amended proposal on 9 September 1993 which reintroduced the binding five year

\footnotetext{
${ }^{10}$ See amendments No. $10,53,60,66$, and 70 , none of which envisage the strict regime of national recycling self-sufficiency which was later adopted by the Council.

${ }^{11}$ See amendments No. 9, 17, 28, 37, 42, 66, 76.

12Europe Environment, 8 June 1993 and 6 July 1993; Agence Europe, 25 June 1993.
} 
targets and took account of islands. ${ }^{13}$ However, the amended proposal rejected both minimum levels of recycled material in packaging and a total phase-out of packaging containing heavy metals, and abandoned any mention of a hierarchy for disposal methods. Just as the Parliament had done, the Commission rejected all of the amendments which would have explicitly allowed widespread national opt-ups, but nevertheless adopted provisions which allowed some autonomous national deviation through the use of environmentally minded economic instruments. The balance between uniform EC standards geared towards free movement of goods, and more stringent national action based on environmental considerations was thus left somewhat unresolved.

Within the Council two coalitions were emerging. The UK, the less developed member states--Spain, Ireland, Greece, Portugal--and to a lesser extent France and Italy favoured a lower recovery target and the omission of binding recycling targets for each type of material. Taking the initiative for this group, the UK proposed dropping any mention of recycling but retaining a goal of 50 percent recovery within ten years. Not surprisingly, this proposal coincided exactly with existing UK plans. ${ }^{14}$

In the event, the opposing coalition of Germany, Denmark and the Benelux states lost the qualified majority vote and the Council adopted a common position which included flexible and less demanding five year targets: 50-65 percent recovery, an overall packaging waste recycling rate of 25-45 percent, a minimum recycling rate of 15 percent for each type of material. ${ }^{15}$ Binding ten year targets were dropped entirely. Instead of limiting special considerations merely to islands, the less developed countries were granted derogations giving them ten years to meet these targets. The common position

\footnotetext{
${ }^{13} \mathrm{OJ}$ C194 19.7.93.

${ }^{14}$ Europe Environment, 28 September 1993 and 12 October 1993; Agence Europe, 6 October 1993 and 1992.

${ }^{15}$ Agence Europe, 3 December 1993 and 17 December 1993; Europe Environment, 9 November 1993 and 16 December 1993.
} 
retained only very limited grounds upon which nations could opt-up for higher targets. States exercising this option were not allowed to cause market distortion and were required to possess sufficient domestic recycling capacity. In essence, the common position foreclosed the possibility of enormous packaging waste exports arising from Germany and other states with extremely ambitious domestic recycling standards.

\section{The European Parliament's Second Reading}

Faced with a common position which had been considerably weakened from an environmental standpoint, the European Parliament tried again during its second reading to reintroduce some of the provisions originally favoured by the Commission and a few which it had put forward in its first reading. However, the scale and ambition of the Environment Committee's second reading was a token gesture compared to its earlier efforts, consisting of only 38 amendments (European Parliament 1994a). The Environment Committee voted on 7 April 1994 to remove any restrictions on maximum targets and decided to nearly double the requirements for specific materials from $15 \%$ to $25 \%$. It also reintroduced the hierarchy of disposal methods which the Council had rejected and reinserted requirements for a minimum level of recycled material in packaging. On 4 May, however, each of these proposed amendments failed to gain sufficient support in the European Parliament, leaving the Council's common position virtually unchanged. ${ }^{16}$

Having survived two readings by the European Parliament, all that remained between the proposal and its adoption was a vote in Council. Before this could occur, however, an unforeseen obstacle appeared in the form of Belgian dissatisfaction with the wording of the proposal, fearing that it would jeopardise its national ecotax. A Belgian defection would have proved fatal to the proposal by depriving it of the necessary 54 votes which represented a

16Europe Environment, 19 April 1994 and 17 May 1994; Agence Europe, 6 May 1994. 
qualified majority vote (QMV). The problem was compounded when Luxembourg threatened to resist the proposal for similar reasons. To make any changes to the proposal at this point would mean altering the text which the Council had received back from the Parliament after its second reading. But some change was necessary to resolve the deadlock, so the proposal passed into the conciliation procedure as provided for in the Treaty. An equal number of MEPs and members of the Council met to hammer out a compromise. Belgium was eventually satisfied with a revised wording of the section on economic instruments designed to reach the recycling targets. Britain, which had also threatened to defect, was equally satisfied that the proposal would not allow national economic instruments which distorted the market, nor would it herald the future wide-spread imposition of Community ecotaxes on member states (Agence Europe, 9 June 1994, 10 June 1994).

During the three conciliation meetings which were held between July and November 1994, representatives from the Parliament, supported by the minority coalition in the Council, tried unsuccessfully to reopen debate on various amendments which were defeated during the second reading. ${ }^{17}$ Putting on a brave face and overlooking the complete failure of the EP to secure many of its specific environmental objectives, Ken Collins declared that "Parliament has won everything on packaging waste" (Agence Europe, 10 November 1994). Perhaps more revealingly, Greenpeace was furious with the directive and the European Greens called the result "a bad directive" engineered by the industrial lobby which posed "a threat to the environment" (Agence Europe, 14/15 November 1994).

The saga of the packaging waste proposal came to an end on 20 December 1994 when Denmark, Germany and the Netherlands lost a qualified majority vote in Council. The directive which was adopted contained all the

${ }^{17}$ Europe Environment, 14 June 1994 and 12 July 1994 and 25 October 1994 and 22 November 1994; Agence Europe, 8 June 1994 and 22 October 1994. 
major features found in the common position, along with the vague section on national economic instruments and a commitment to revisit the entire issue of waste again in ten years with a view to substantially increased recycling targets. The following table chronicles the development of the directive through each phase of the decisionmaking process, noting the introduction and demise of various key provisions.

Table 3 Development of the Directive

\begin{tabular}{|c|c|c|c|c|c|c|c|c|c|}
\hline & Comm1 & Comm2 & EPEC1 & EP1 & Comm3 & \begin{tabular}{l|} 
Common \\
Position
\end{tabular} & EPEC2 & EP2 & Adopted \\
\hline Per Capita Limits & Yes & No & No & No & No & No & No & No & No \\
\hline $\begin{array}{l}\text { Minimum Use of } \\
\text { Recycled Materials }\end{array}$ & No & No & Yes & Yes & No & No & Yes & No & No \\
\hline Hierarchy & Yes & No & Yes & Yes & No & No & Yes & No & No \\
\hline Opt-ups & No & No & \begin{tabular}{|l|} 
Very \\
Broad \\
\end{tabular} & Limited & Limited & $\begin{array}{l}\text { Very } \\
\text { Limited } \\
\end{array}$ & \begin{tabular}{l|} 
Very \\
Limited \\
\end{tabular} & $\begin{array}{l}\text { Very } \\
\text { Limited } \\
\end{array}$ & $\begin{array}{l}\text { Very } \\
\text { Limited } \\
\end{array}$ \\
\hline Derogations & No & No & \begin{tabular}{|l|}
$\begin{array}{l}\text { Possibly } \\
\text { Islands }\end{array}$ \\
\end{tabular} & \begin{tabular}{|l|}
$\begin{array}{l}\text { Possibly } \\
\text { Islands }\end{array}$ \\
\end{tabular} & \begin{tabular}{|l|}
$\begin{array}{l}\text { Possibly } \\
\text { Islands }\end{array}$ \\
\end{tabular} & Yes & Yes & Yes & Yes \\
\hline $\begin{array}{l}\text { Five Year Targets } \\
\text {--total recovery rate } \\
\text {--total recycling rate } \\
\text {--recycling rate for } \\
\text { each type of material } \\
\end{array}$ & $\begin{array}{l}60 \% \\
40 \% \\
\end{array}$ & No & $\begin{array}{l}60 \% \\
40 \% \\
\end{array}$ & $\begin{array}{l}60 \% \\
40 \% \\
\end{array}$ & $\begin{array}{l}60 \% \\
40 \% \\
\end{array}$ & $\begin{array}{l}50-65 \% \\
25-45 \% \\
15 \% \\
\end{array}$ & $\begin{array}{l}50 \% \\
25 \% \\
25 \% \\
\end{array}$ & $\begin{array}{l}50-65 \% \\
25-45 \% \\
15 \% \\
\end{array}$ & $\begin{array}{l}50-65 \% \\
25-45 \% \\
15 \% \\
\end{array}$ \\
\hline $\begin{array}{l}\text { Ten Year Targets } \\
\text {--total recovery rate } \\
\text {--recycling rate for } \\
\text { each type of material } \\
\text {--maximum landfill } \\
\text { and burning } \\
\text {--heavy metals ban }\end{array}$ & $\begin{array}{l}90 \% \\
60 \% \\
10 \% \\
\text { No } \\
\end{array}$ & $\begin{array}{l}90 \% \\
60 \% \\
10 \% \\
\text { No } \\
\end{array}$ & $\begin{array}{l}90 \% \\
60 \% \\
10 \% \\
\text { Yes } \\
\end{array}$ & $\begin{array}{l}90 \% \\
60 \% \\
10 \% \\
\text { No } \\
\end{array}$ & $\begin{array}{l}90 \% \\
60 \% \\
10 \% \\
\text { No } \\
\end{array}$ & $\begin{array}{l}\text { No } \\
\text { No } \\
\text { No } \\
\text { No } \\
\end{array}$ & $\begin{array}{l}\text { No } \\
\text { No } \\
\text { No } \\
\text { No } \\
\end{array}$ & $\begin{array}{l}\text { No } \\
\text { No } \\
\text { No } \\
\text { No } \\
\end{array}$ & $\begin{array}{l}\text { No } \\
\text { No } \\
\text { No } \\
\text { No } \\
\end{array}$ \\
\hline
\end{tabular}

Note: $\quad$ Comm1 $=$ Commission pre-draft objectives

Comm2=Commission first draft

EPEC1=First report by the Environment Committee of the European Parliament EP1=First reading by the European Parliament

Comm3=Revised Commission proposal

EPEC2 $=$ Second report by the Environment Committee of the European Parliament

EP2=Second reading by the European Parliament

\section{Institutional Roles}

Commission as Agenda Setter and Policy Entrepreneur

As the formal initiator of all legislative proposals within the EC, the Commission's power stems from its ability to set the agenda (Wallace, Wallace and Webb 1983, Nugent 1991, Peters 1994, Majone 1994; Marks, Hooghe and 
Blank 1994). If in fact that power is more than illusory, one would expect to find that the Commission exercised considerable control over the shape of the packaging waste directive, with a clear resemblance between the Commission's pre-draft objectives and the provisions found in the eventual agreement. Alternatively, development of the directive might illustrate the relative impotence or irrelevance of the Commission's agenda setting powers. In this case there would be little or no relation between the Commission's predraft plans and the content of the directive after it had survived protracted negotiation between EC institutions and undergone successive rounds of amendment.

The case of the waste packaging directive reveals the ability of the Commission formally to set the agenda and the ability of Parliament to affect the pace and content of EC legislation. Stringent recovery and recycling standards, five year targets, per capita waste limits and a hierarchy of disposal methods may have been the product of extensive consultation with a variety of interests, including NGOs and technical experts from each member state, but these provisions could only be put on the formal agenda if the Commission included them in the draft directive.

For many observers of European integration, agenda setting is synonymous with controlling the shape of first drafts. It is not difficult to find evidence supporting this conception of agenda setting--the Commission's right of initiative, its direct dialogue with a plethora of actors, its extensive network of technical experts and its role as policy entrepreneur yield considerable control over the timing and content of legislative proposals, including the one on packaging waste. However, this study clearly shows the need for a more demanding conception of agenda setting. Despite the obvious window of opportunity for a packaging waste directive, the Commission failed to secure most of its original primary objectives. The per capita waste target and the hierarchy of disposal methods were dropped even before the first 
draft appeared, the recovery and recycling targets were substantially reduced in order to meet the demands of the member states. That the targets were effectively reduced to the lowest common denominator is discussed further below.

Even if one assumes a certain amount of gamesmanship, whereby the Commission habitually puts forward extremely ambitious proposals and targets which it knows will be sacrificed during subsequent negotiations with the Council, the weakness of the Commission as an agenda-setter is striking. Although from Table 3 the change in specific targets from the pre-draft objectives to the final adoption, consisting of a few percentage points, might appear insignificant and thus a clear case of Commission agenda-setting, it was precisely these few points upon which the possibility of expensive state obligations turned. As noted in more detail below, the provisions in the final version of the directive do not reflect a compromise situated in the middleground between Commission and Council objectives. Rather, the directive represented the least common denominator because the Commission was forced to capitulate to a qualified majority in the Council.

\section{Influence of the European Parliament}

The 1987 Single European Act significantly increased the powers of the EP. The previous requirement that the Council merely seek the opinion of Parliament before adopting legislation gave way to the co-operation procedure, whereby directives face the very real possibility of amendment or rejection during two readings by the EP. Evidence since 1987 suggests that the co-operation procedure, with provided the Parliament with two readings of many proposals, did indeed bestow significant new powers on the EP and elevate its role from that of a hapless spectator to an important partner in the EC policymaking dialogue, often working in conjunction with the Commission against the Council (Jacobs, Corbett and Shackleton 1992). Under the co- 
decision procedure the EP enjoys even greater power to introduce substantial amendments to or outrightly block the Council's common position.

This has been particularly apparent in the field of EC environmental policy where the EP has altered or rejected a significant number of major directives (Arp 1992, Earnshaw and Judge 1993, Judge and Earnshaw 1994). Much of the EP's success has been due to the ideological devotion and tireless efforts of Ken Collins and the other members of its Environment Committee (Judge 1993). Based on past experience one would expect to see the European Parliament strive to "green" the packaging waste directive during its two readings of the proposal. It would also not be surprising to find that the Parliament worked with the Commission to maintain or strengthen the environmental focus of the proposal.

In this respect, two lessons emerge from the saga of the packaging waste directive. First, that the "greening" effect of the Parliament does not necessarily occur. As this study reveals, this is explained by distinguishing between the efforts of the Environment Committee and those of the Parliament itself. Under the leadership of Ken Collins, the Environment Committee acted predictably during both its readings and reintroduced the stringent environmental standards originally proposed by the Commission. But the Parliament did not always follow the advice of its Environment Committee. Amendments supported by the Committee, aimed at eliminating limits on maximum recycling rates, establishing a hierarchy of disposal methods, allowing considerable room for national opt-ups, requiring a minimum amount of recycled material in packaging, and banning heavy metals in packaging were all defeated during either the first or second reading.

Second, and perhaps more significant, the formal powers of the Parliament to shape EC policy were clear--for some amendments the difference between success and failure was a matter of 22 votes at the second 
reading. ${ }^{18}$ It is impossible to construct a perfect counterfactual scenario based on what might have happened if these 22 votes had been forthcoming. However, two possibilities deserve consideration. The qualified majority coalition could have accepted the amendments, in which case Denmark, Germany and the Netherlands would have been free to achieve high recovery and recycling standards despite the effects which this would have had on neighbouring states. In addition, the hierarchy would have made it politically more difficult for states to avoid prevention as a primary objective, and also more difficult for them to pursue less desirable forms of waste disposal, particularly composting and incineration. Alternatively, an undivided Parliament could have blocked Council action by replacing the common position with an unpopular alternative. If either of these situations had occurred it would have demonstrated the very real agenda-setting power of the Parliament.

Taking these two lessons together, the study demonstrates the limits of partnership between the Parliament and Commission. Needing to muster only a quality majority vote in the Council under the terms of the SEA, one would predict that by working together--in essence, pooling their formal powers--the Commission and the increasingly powerful EP would achieve a number of their objectives and dictate the shape of EC policy.

As the case of the packaging directive makes clear, the interests of the Commission and the Parliament do not always coincide. During its first reading, the Environment Committee and the Parliament as a whole reintroduced provisions which the Commission had abandoned in order to gain Council support. Commission encouragement was also noticeably absent during the second reading, which left the Environment Committee, already

\footnotetext{
${ }^{18}$ This was due to the differing positions of the parties in the European Parliament. Most EP Socialists followed the lead of the Environment Committee. The Greens hated the watered down proposal and put forward a substitute. They might have supported the Environment Committee but preferred no action to bad action. The EPP and the RDE resisted any move towards more stringent standards.
} 
lacking sufficient support in Parliament, alone to press for these amendments. During both readings the Commission also refused to adopt amendments favoured by the Environment Committee or the Parliament which would have strengthened the environmental profile of the directive, including minimum amounts of recycled material in packaging and a ban on packaging containing heavy metals. Furthermore, the Commission never endorsed the greenest amendment favoured by the Environment Committee--that environmentally progressive states be given considerable discretion to opt-up for more stringent national standards.

\section{Council of Ministers}

Changes to the structure of the EC policymaking process brought about by the SEA also allow predictions about the Council's role in the packaging directive. First, the SEA altered the dynamics of bargaining within the Council by increasing the use of qualified majority voting. With the formal demise of the national veto one would expect that environmental directives would contain targets and standards significantly above the prevailing lowest common denominator. Although it is debatable which institutions and pressures were primarily responsible for the conception and adoption of the SEA, there is general agreement that Article $100 \mathrm{~A}$ expedited completion of the common market and unblocked a substantial number of directives which had previously languished under the constraints of the Luxembourg Compromise (Moravcsik 1991, Garrett 1992, Sandholtz and Zysman 1989). And it was the bargaining dynamics inherent to the Luxembourg Compromise which often prevented Community environmental standards from surpassing the lowest common denominator (Weiler 1991, Golub 1994a, 1994b, Rehbinder and Stewart 1985, Haigh 1992).

In fact, development of the packaging directive confirms the fears expressed by "green" member states during the SEA negotiations--that 
majority voting would remove their veto and allow European environmental standards to be dragged down to the lowest common denominator. ${ }^{19}$ I would suggest that the lowest common denominator obtains when a directive requires no member state to introduce significant changes in order to upgrade their environmental practices. For the purposes of the present discussion, the lowest common denominator consists of combining information from Table 1 and Table 2, each of which provides a view of prevailing conditions in the various member states.

At first it appears from Table 2 that under the terms of the directive many states would be forced to introduce strict recycling laws. However, comparing the requirements set out in the directive with the recycling levels already achieved in the member states (Table 1), which in many cases do not reflect advances already made since 1987, one finds that only Irish paper, Belgian aluminium and Portuguese aluminium present any problems whatsoever. Table 2 shows that recycling of Belgian aluminium was already scheduled to increase regardless of the directive. Furthermore, Portugal and Ireland were given until 2005 to meet the required recycling and recovery targets. Thus in almost all cases the directive actually approximated recycling rates which already existed or were already planned throughout the Community. In the remaining few instances it allowed substantial derogations which postponed any required changes to state practice. Thus there is little evidence that "the grubbier majority will under the directive have to come up with plans to do much more," and considerable evidence that the directive represented the lowest common denominator (Economist, 18 December 1993).

The only provision which might have posed problems for the member states and thus represented a move beyond the lowest common denominator was the target for plastic, a material whose recycling involves higher cost and

${ }^{19} \mathrm{As}$ discussed below, in this case the opt-out provisions provided by Article $100 \mathrm{~A}(4)$ of the Single European Act offered no escape route for environmentally-minded member states. 
more advanced technology. Calculating the rate of plastic recycling raises a number of definitional problems and is further complicated by a general lack of hard data. But even in this area, close inspection of existing and planned plastic recycling in the member states suggests that the directive is little more than a lowest common denominator. As of 1993, France, Italy, and the UK already recycled $17-31 \%$ of their plastic packaging material, with plans to significantly increase these rates by 2000.20 Germany, Belgium, Denmark, and the Netherlands had recycling plans which far surpassed the targets established by the directive. Each of the remaining five states had plans to increase overall plastic recycling and had already started to recover specific items such as bottles for plastic drinks. Ireland, Portugal and Greece particularly benefited from the 10 year deadline.

The fact that the directive basically reflected the lowest common denominator highlights that even with the structural changes brought about by the SEA, power ultimately lies with the national representatives in the Council of Ministers--more precisely, with a qualified majority of these ministers. Although the Council adopted an enormous number of amendments put forward by the Parliament and Commission, which would indicate that the power of agenda-setting resided in these latter institutions, these amendments primarily affected cosmetic changes to the packaging proposal. Even with clear formal powers to set the agenda and control the content of directives, the Commission and Parliament were unable to dictate stringent environmental standards in the packaging directive because, in the end, their objectives were unpalatable to a qualified majority of member states. Of course things would have been totally different if the commission or parliament had exercised their formal powers and dictated the content of the proposal put before the Council

${ }^{20}$ These rates combine mechanical as well as chemical recycling, and are also based on a survey of each state. See UNECE (1993). 
for decision. In this case, the fact is that they did not, or could not, because it would have produced unappealing consequences.

The lowest common denominator result also demonstrates the potential for some states, in this case particularly Germany, to lose under qualified majority voting. Instead of uniform and stringent targets favoured by the Commission, Germany, Denmark and the Netherlands, a QMV saw fit to establish easily met targets which the minority coalition was forbidden from exceeding except under strict conditions of national recycling self-sufficiency. By emphasising national self-sufficiency in waste recycling, as well as the importance of each state being able to meet the agreed targets, the directive provides Britain, France and other states legal grounds on which to block such exports. As mentioned at the start of this paper, prior to the directive the ECJ would probably have considered such restrictions discriminations on trade and therefore contrary to Article 30 . It should be noted that even after harmonisation Germany and the other member states which lost the QMV could still opt-up for more stringent domestic recycling standards under Article $100 \mathrm{~A}(4)$, but in doing they would not regain political options which the directive curtailed because they could not force other states to accept unwanted waste shipments.

\section{Refining Integration Theory}

What does this study of the packaging directive tell us about the current debate on the nature of integration? It clarifies the competing claims of those who defend state-centric models and those who characterise integration as an accumulation of supranational powers or a diffusion of power towards multilevel government, and it suggests a method by which these claims may be reconciled or refuted. Multi-level government models posit that power has moved away from national executives and away from the Council as a plethora of actors mobilise and exert influence at various points in the decisionmaking 
process. State-centric models posit instead that the Council has retained a monopoly on real power and that other EC institutions play either a limited or subservient role in the policymaking process.

The packaging case suggests that either of these theories taken alone lacks explanatory power. It suggests further that the dominant theories do not directly confront one another but are in fact talking about different aspects of integration. The diffusion model is not comprehensive because it conflates influence with power. It is undeniable that the accessibility of the Commission and EP allows mobilisation; there is ample evidence that direct dialogue takes place between these two institutions and NGOs, regions, local government, individuals, single firms and the separate governments. The packaging and recycling industries as well as Greenpeace and other environmental organisations obviously affected how members of the Commission and of the EP worded the original proposal and its amendments.

Unfortunately, the diffusion literature often equates influence at draft and pre-draft stages with having power over final decisions. This study suggests that the true test of whether power has been diffused is whether or not one can point to legislation which was amended and then adopted in the face of member state opposition or to proposed legislation which was blocked by the Commission or EP despite Council support. ${ }^{21}$ Unless either of these two instances can be demonstrated, then the most one can say is that the dialogue produced by the participation of multiple actors yields ideas which are in turn used as resources by the Council. As Marks correctly points out, on issues that are not highly polarised among member states, supranational

\footnotetext{
${ }^{21}$ Due to space constraints, this study focuses on shifting legislative power and will not address the role of soft law or the ECJ in undermining national autonomy, nor instances where the Commission or Parliament can take direct administrative or legislative action which impinges on national prerogatives without involving the Council. It is fully recognised that some theorists might consider these equally if not more important measures of diffusion ignored by state-centric models.
} 
actors and epistemic communities can influence the content and direction of policy through skilful persuasion.

This is indeed one form of agenda setting and involvement, but, as Marks and others concede, it does not undermine the power of states (instead, the persuasion of analytical arguments replaces the exercise of power) (Marks, Hooghe and Blank 1994:22). If anything it supports those who claim that the variety of actors serves merely a functional role--a reservoir of creative ideas which are sometimes embraced by the Council to advance the agendas of the member states. To this extent, involvement and influence differ markedly from power. In terms of institutional influence, Parliament and the Commission can provide a repertoire of policy options. But in terms of power they can not prescribe specific policy outcomes. The ability to get people thinking about certain ideas constitutes an important but weak form of agenda setting which does not threaten state centric models. It has been argued, for example, that the Commission played just such a role in the development of the Single European Act (Dehousse and Majone 1994). The crucial point is that when Commission and EP ideas are not embraced by the Council, the mobilisation of actors produces no tangible results and no influence whatsoever, short of preventing Council action and thereby paralysing the entire legislative process.

But as the packaging example illustrates, state centric models are of equally limited value because they overestimate the ability of the Council to dominate the other institutions, and because they conflate collective Council authority with the preservation of national sovereignty and national autonomy. The first of these limitations becomes clear if we apply the previously mentioned two-pronged test of where power actually lies to the existing empirical evidence. It is difficult to reconcile the expanded formal powers of the EP with the suggestion that the Council retains total control of the integration process. As mentioned earlier in this paper, even limiting oneself 
to the field of environmental policy it is possible to identify several cases where the EP altered or defeated the Council's common position. In the packaging case, the Environment Committee of the Parliament was powerless to dictate anything to the Council, but if the requisite number of votes had been forthcoming in the Parliament the clear power of that institution would have become apparent. This illustrates an important clarification to the ongoing theoretical debate: when the involvement of multiple actors produces ideas which the Commission and EP then force into the final directive through amendments, diffusion of power away from the Council is undeniable. Of course the onus is on diffusion theorists to demonstrate that their studies identify a shift of power and not merely contributing factors which influenced the Council to vote in a certain way (Sandholtz and Zysman 1989, Hooghe and Keating 1994, Hooghe and Marks 1995).

It becomes clear at this point that the competing theories are actually speaking in different languages. Whereas state-centric models focus exclusively on power, diffusion models focus on influence. Thus Marks sets out to show that "supranational institutions...have independent influence in policy making that cannot be derived from their role as agents of state executives," while Moravcsik devotes his analysis to assessing the expanded prerogative of national executives (Marks, Hooghe and Blank, 1994:8). In cases other than the two scenarios of shifting power mentioned above, these approaches are actually complementary--by generating ideas and policy proposals which the member states might not otherwise have thought of, the Commission, EP and NGOs demonstrate considerable influence over the integration process without exercising actual power over individual decisions. Supranational organisations are not inherently subservient to the will of the member states, but it would be equally simplistic to claim that the technical expertise, organisational capacity or range of policy options available to the Commission and other supranational actors are decisive in shaping the content 
of each piece EC directive (Majone, 1994; Marks, Hooghe and Blank 1994:26). Models such as the one presented by Moravcsik could subsume much of the diffusion evidence by recognising this distinction and conceding the influence but not the power of bodies other than the Council.

The second weakness of state-centric models is that by focusing exclusively on inter-institutional relations and the collective power of national executives in Council, they obscure the fact that some individual national executives inevitably become "losers" under QMV. Having lost the fight, these unfortunate states are faced with binding European legislation which curtails their own choice of policies, thus eroding their individual national autonomy and national sovereignty. Short of pulling out of the EC, individual national executives have no choice but to live with what they regard as unnecessary or misdirected laws. The case of the packaging directive clarifies this point. By adopting a lowest common denominator approach, the directive made it impossible, in fact illegal, for Germany, Denmark and the Netherlands to pursue what they considered perfectly reasonable environmental objectives-meeting stringent environmental standards by whatever means possible, including the export of large quantities of packaging waste. There is no evidence that these three states were in any way compensated with side payments or concessions in other policy areas, nor that their national governments actually desired laxer standards and secretly welcomed defeat at Community level in a manner similar to the "slack cutting" found in the Belgian privatisation or the Italian monetary discipline (Milward 1992, 1993, Moravcsik 1994). The lesson is clear: for many directives there will always be at least one loser. Some states will either be forced to adopt expensive and presumably unpopular new policies, or to forego more stringent standards preferred by their own citizens.

Thus Moravcsik's claim that "where chief executives have divergent goals, we should expect less cooperation" drastically misrepresents Council 
dynamics (Moravcsik, 1994:58). A more accurate rule would hold that where executives have divergent goals, those who find themselves on the losing end of a QMV always forfeit the ability to pursue their domestic agendas free from Community constraints, and are sometimes forced to pursue the majority's agenda using policy instruments chosen by the majority. It should also be recalled that if the EP had secured 22 more votes during its second reading and been able to muster a QMV in Council, the situations might easily have been reversed, with environmentally progressive states ending up the winners and a different minority coalition facing unpleasant but nevertheless binding European targets. In either case, these situations--and as will be discussed below there may be literally tens of thousands--reveal quite dramatically that national executives do not "bolster their control over domestic agenda-setting by cartelizing international policy initiation" (Moravcsik, 1994:11).

The third shortcoming of state-centric models is that they ignore the effects of mutually beneficial collective action by Council on the residual autonomy available to the member states. Even assuming that the Council produces laws which on the whole satisfy each of the member states, obligations undertaken at the EC level place considerable restrictions on the autonomy and flexibility of each individual country. Even the lowest common denominator limits the options of the less developed countries by preventing backsliding, setting compliance deadlines and recycling targets which otherwise might have been repealed or amended by the national executive. Thus the current national executive who negotiated the EC law faces a restricted range of policy options at the national level. In the case of the packaging directive, by being forced to actually carry out existing national recycling plans, EC law clearly restricted the autonomy of the British, French, Italian and Belgian governments. This loss of national executive autonomy becomes even more apparent when new national executives are unhappily 
bound by EC obligations entered into by previous administrations. In the current case, a new government in any of the previously listed states will have to comply with mandatory EC recycling targets with which they may or may not agree.

It is therefore not only diffusion to other institutions which erodes sovereignty but the diffusion from individual state executives to the collective will of the Council. Moravcsik admits that states lose "external sovereignty" but he wrongly equates "cutting slack" with enhancing the overall manoeuvrability of national executives. In fact, by fostering wider and deeper integration, national executives cut themselves slack at the price of painting themselves into a corner--they gain the luxury of legislating free from domestic constraints, but exercise this freedom in an ever diminishing policy space. Confined by a burgeoning body of EC law, this steadily shrinking policy space is inherited by each successive national administration.

It is for this reason that Moravcsik's assertion that "EC policies tend, on balance, to reinforce the domestic power of national executives" appears so unconvincing (Moravcsik 1994:52). For it is not the five examples of intergovernmental bargaining over high politics, which he like Milward before him defend quite convincingly, which are "broadly representative" of $\mathrm{EC}$ institutions and policies, but examples like the packaging waste proposal and the 24,120 EC regulations and directives which were in force by the end of 1992 which constitute the real test of whether or not "international institutions undermine domestic sovereignty" (Moravcsik, 1994:64). This question can only be answered by considering the full effect of EC law on national autonomy. Although a daunting task, the persuasiveness of statecentric models would be greatly enhanced if they could show that this huge body of EC law, which in some cases is scheduled to account for over $80 \%$ of national legislation by the turn of the century, did not restrict the policy options of national leaders. 
Nor can examples such as the packaging waste directive be easily dismissed as unrepresentative by claiming that "few governments have any preexisting [environmental] policies" which might conflict with EC actions (Moravcsik 1994:53). Besides being factually incorrect, this claim is also irrelevant; even if there had been little national environmental law on the books, at one point or another most member states have adamantly resisted EC environmental proposals because they would have entailed enormous costs. Intense disagreements between the Commission and Council, and within the Council itself almost always led to watered down directives and lowest common denominator legislation. Nevertheless, since 1967 the corpus of EC law has steadily expanded, with a corresponding constriction of national autonomy.

It is for this reason that the ambiguous concept of "pooled sovereignty", which conflates preservation of national legislative autonomy with the attainment of national objectives, has been used so effectively to take the sting out of European integration (Keohane and Hoffmann 1990, Milward 1992, 1993, Golub 1994a). Pooled sovereignty implies that states sacrifice sovereignty in order to attain national political goals which can better be met through Community legislation. National security and trade liberalisation are the two examples usually cited. As realists proponents of state-centric models point out, for each state membership in the Community must be positive sum game on aggregate, or at least prove less costly than secession. But even if pooled sovereignty enables states to attain their desired goals, they must accept a restriction on their legislative discretion and thus a curtailment of executive autonomy which authors such as Moravcsik fail to recognise.

\section{Conclusion}

This study has traced the development of the packaging waste proposal in order to assess the role of various Community institutions and thereby 
identify central features of the integration process. The premise of the analysis was that structural changes introduced by the SEA and reinforced by the TEU eroded the authority of the Council and formally empowered the Commission and the European Parliament. This shift of power should have been apparent in the Commission's and Parliament's ability to set the agenda and exercise substantial control over the eventual provisions of the directive. Moreover, the reputation of these two institutions as considerably "greener" than the Council should have led to stringent environmental standards well above the prevailing lowest common denominator.

However, an examination of the protracted negotiations and a comparison of the original proposal with the final directive reveals no evidence of a weakened Council or of the supposed agenda-setting powers of the other major institutions. The final directive contained none of the controversial provisions originally favoured by the Commission and supported by the Parliament, reflecting instead the lowest common denominator of waste recovery and recycling rates in the member states. In securing the adoption of its common position, the Council met with little effective resistance from the Commission or Parliament. The Commission abandoned the contentious aspects of its proposal early on in the negotiating process, and failed to support their reintroduction during Parliament's two readings. Besides revealing the limits of partnership between Commission and Parliament, the study also discovered a further level of complexity surrounding the role of the latter; the ineffectiveness of the second reading stemmed from the fact that the Parliament as a whole refused to adopt the amendments put forward by its remarkably determined Environment Committee.

Although the study focused on the packaging waste directive, lessons from this one example help clarify central issues in the two competing conceptions of European integration. The role of the various actors throughout the development of the directive shows the fundamental difference 
between influence and power, a distinction which is often lost in discussions of integration. Until advocates of diffusion and state dominance acknowledge the implications which flow from this distinction they will continue to speak at cross purposes instead of directly addressing points of contention.

It is suggested that state centric models could subsume much of the diffusion literature by conceding the influence but not the power of the Commission and Parliament in the decisionmaking process. As the packaging case demonstrates, all the technical expertise, agenda-setting and influence of the Commission and Parliament came to nothing, unless these two institutions have the determination to risk paralysing the decisionmaking process, because ultimately power resides with the Council; with a qualified majority in Council, to be more precise.

This suggests that instead of documenting instances where mobilisation and dialogue between an expanding array of actors merely influenced eventual Council decisions, diffusion theorists could sharpen their criticisms of state dominance by focusing instead on cases where action was taken or prevented despite Council opposition. State-centric models are particularly susceptible to such criticism because they overlook the expansion of the Parliament's formal powers and how this may lead to amendment or paralysis of Council decisions. Additionally, state-centric models overlook the impact which EC legislation such as the packaging directive, produced through qualified majority voting, has on the residual ability of national executives to control domestic political agendas when it imposes policy objectives and instruments.

Finally, by narrowing their attention to power rather than influence, diffusion theorists can capitalise on what is perhaps the most blatant omission of state-centric models: the failure to recognise that the enormous body of binding EC laws, even if it "cuts slack" for national executives and fosters the interests of every member state, essentially leaves individual national 
executives with more and more control over less and less, until they achieve absolute control over nothing at all.

\section{References}

Arp, Henning (1992) "The European Parliament in European Community Environmental Policy," EUI Working Paper EPU No. 92/13 (Florence:European University Institute).

Club de Bruxelles (1994) Business and European Environmental Policies (Brussels:Club de Bruxelles).

Dehousse, R. and G. Majone (1994) "The Institutional Dynamics of European Integration: From the Single Act to the Maastricht Treaty," in Stephen Martin, The Construction of Europe (Dordrecht:Kluwer).

Earnshaw, D. and D. Judge (1993) "The European Parliament and the Sweeteners Directive: From Footnote to Inter-Institutional Conflict," 31 Journal of Common Market Studies 103.

European Parliament (1993) Report of the Committee on the Environment, Public Health and Consumer Protection, Doc A3-0174/93, 8 June 1993.

European Parliament (1994a) Report of the Committee on the Environment, Public Health and Consumer Protection, Document A3-0237/94, 11 April 1994.

Garrett, G. (1992) "International Cooperation and Institutional Choice: The EC's Internal Market," 46 International Organization 533 (1992).

Golub, J. (1994a) British Integration into the EEC: A Case Study in European Environmental Policy (Oxford University doctoral thesis, 1994).

Golub, J. (1994b) "The Pivotal Role of British Sovereignty in EC Environmental Policy," EUI Working Paper RSC No. 94/17 (Florence:European University Institute).

Haigh, N. (1992) EEC Environmental Policy and Britain (London:Longman).

Hooghe, L. and M. Keating (1994) "The Politics of EU Regional Policy," 1 Journal of European Public Policy 367 (1994).

Hooghe, L. and G. Marks (1995) "Channels of Subnational Representation in the European Union," (mimeo).

House of Lords (1993) Select Committee on the European Communities, 26th Report (199293).

Jacobs, F., R. Corbett and M. Shackleton (1992) The European Parliament (Essex:Longman). Judge, D. (1993) "'Predestined to Save the Earth': The Environment Committee of the European Parliament," in David Judge ed., A Green Dimension for the European Community: Political Issues and Processes (London:Frank Cass).

Judge, D. and D. Earnshaw (1994) "Weak European Parliament Influence? A Study of the Environment Committee of the European Parliament," 29 Government and Opposition 262. 
Keohane, R. and S. Hoffmann (1990) "Conclusions: Community Politics and Institutional Change," in William Wallace, ed., The Dynamics of European Integration (London:Pinter).

Krämer, L. (1993) "Environmental Protection and Article 30 EEC Treaty," 30 Common Market Law Review 111.

Majone, G. (1994) "The European Community as a Regulatory State" (mimeo).

Marks, G. L. Hooghe and K. Blank (1994) "European Integration and the State," presented at APSA meeting, New York, 1-4 September, 1994.

Milward, A. (1992) The European Rescue of the Nation-State (London:Routledge).

Milward, A. et al. eds. (1993) The Frontier of National Sovereignty (London: Routledge).

Moravcsik, A. (1991) "Negotiating the Single European Act," National Interests and Conventional Statecraft in the European Community," 45 International Organization 19.

Moravcsik, A. (1994) "Why the European Community Strengthens the State: Domestic Politics and International Cooperation," Harvard Centre for European Studies, Working Paper Series \#52.

Newman, O. and A. Foster (1993) European Environmental Statistics Handbook (Gale Research International Ltd.).

Nugent, N. (1991) The Government and Politics of the European Community (Basingstoke: Macmillan).

Peters, G. (1994) "Agenda-setting in the European Community," 1 Journal of European Public Policy 9.

Rehbinder, E. and R. Stewart (1985) Environmental Protection Policy (Berlin:de Gruyter).

Sandholtz, W. and J. Zysman (1989) "1992: Recasting the European Bargain," 42 World Politics 95.

Sexton, T. (1991) "Enacting National Environmental Laws More Stringent than Other States' Laws in the European Community," 24 Cornell International Law Review 563.

UNECE (1993) Management of plastic Wastes in the ECE Region (New York:United Nations Publications).

UNEP (1991) United Nations Environment Programme, Environmental Data Report 1991.

UNEP (1992) United Nations Environment Programme, Environmental Data Report 1992.

UNEP (1994) United Nations Environment Programme, 17 Industry and the Environment (April-June 1994).

van Goethem, A. (1993) Packaging Waste The Regulatory Framework in the Twelve EU Member States (Brussels:Europe Information Service).

von Wilmowsky, P. (1993) "Waste Disposal in the Internal Market: The State of Play After the ECJ's Ruling in the Walloon Import Ban," 30 Common Market Law Review 541.

Wallace, H., W. Wallace and C. Webb eds. (1983) Policy-Making in the European Community (Chicester:Wiley).

Weiler, J. (1991) "The Transformation of Europe," 100 Yale Law Review 2403. 


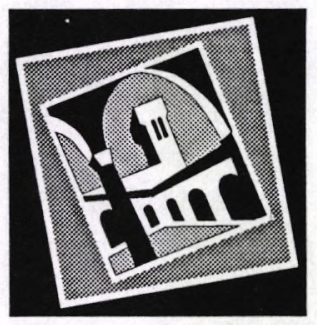

EUI WORKING PAPERS

EUI Working Papers are published and distributed by the European University Institute, Florence

Copies can be obtained free of charge - depending on the availability of stocks - from:

The Publications Officer

European University Institute

Badia Fiesolana

I-50016 San Domenico di Fiesole (FI)

Italy 


\title{
Publications of the European University Institute
}

To

\author{
The Publications Officer \\ European University Institute \\ Badia Fiesolana \\ I-50016 San Domenico di Fiesole (FI) - Italy \\ Telefax No: $+39 / 55 / 4685636$ \\ E-mail: publish@datacomm.iue.it
}

From

Name

Address.

$\square$ Please send me a complete list of EUI Working Papers $\square$ Please send me a complete list of EUI book publications

$\square$ Please send me the EUI brochure Academic Year 1996/97

Please send me the following EUI Working Paper(s):

No, Author

Title:

No, Author

Title:

No, Author

Title:

No, Author

Title:

Date

Signature 


\section{Working Papers of the Robert Schuman Centre}

RSC No. 94/1

Fritz W. SCHARPF

Community and Autonomy Multilevel

Policy-Making in the European Union *

RSC No. 94/2

Paul McALEAVEY

The Political Logic of the European

Community Structural Funds Budget:

Lobbying Efforts by Declining Industrial

Regions

RSC No. $94 / 3$

Toshihiro HORIUCHI

Japanese Public Policy for Cooperative

Supply of Credit Guarantee to Small Firms -

Its Evolution Since the Post War and Banks'

Commitment

RSC No. 94/4

Thomas CHRISTIANSEN

European Integration Between Political

Science and International Relations Theory:

The End of Sovereignty *

RSC No. 94/5

Stefaan DE RYNCK

The Europeanization of Regional

Development Policies in the Flemish Region

RSC No. 94/6

Enrique ALBEROLA ILA

Convergence Bands: A Proposal to Reform the EMS in the Transition to a Common

Currency

RSC No. 94/7

Rosalyn HIGGINS

The EC and the New United Nations

RSC No. 94/8

Sidney TARROW

Social Movements in Europe: Movement

Society or Europeanization of Conflict?

RSC No. 94/9

Vojin DIMITRIJEVIC

The 1974 Constitution as a Factor in the Collapse of Yugoslavia or as a Sign of

Decaying Totalitarianism
RSC No. 94/10

Susan STRANGE

European Business in Japan: A Policy

Crossroads?

RSC No. 94/11

Milica UVALIC

Privatization in Disintegrating East European

States: The Case of Former Yugoslavia

RSC No. 94/12

Alberto CHILOSI

Property and Management Privatization in Eastern European Transition: Economic Consequences of Alternative Privatization Processes

RSC No. 94/13

Richard SINNOTT

Integration Theory, Subsidiarity and the Internationalisation of Issues: The

Implications for Legitimacy *

RSC No. 94/14

Simon JOHNSON/Heidi KROLL

Complementarities, Managers and Mass

Privatization Programs after Communism

RSC No. 94/15

Renzo DAVIDDI

Privatization in the Transition to a Market

Economy

RSC No. 94/16

Alberto BACCINI

Industrial Organization and the Financing of

Small Firms: The Case of MagneTek

RSC No. 94/17

Jonathan GOLUB

The Pivotal Role of British Sovereignty in EC Environmental Policy

RSC No. 94/18

Peter Viggo JAKOBSEN

Multilateralism Matters but How?

The Impact of Multilateralism on Great

Power Policy Towards the Break-up of

Yugoslavia 
RSC No. 94/19

Andrea BOSCO

A 'Federator' for Europe: Altiero Spinelli and the Constituent Role of the European Parliament

RSC No. 94/20

Johnny LAURSEN

Blueprints of Nordic Integration. Dynamics and Institutions in Nordic Cooperation, 1945-72

\section{棌棌}

RSC No. 95/1

Giandomenico MAJONE

Mutual Trust, Credible Commitments and the Evolution of Rules for a Single

European Market

RSC No. 95/2

Ute COLLIER

Electricity Privatisation and Environmental

Policy in the UK: Some Lessons for the

Rest of Europe

RSC No. $95 / 3$

Giuliana GEMELLI

American Influence on European

Management Education: The Role of the

Ford Foundation

RSC No. 95/4

Renaud DEHOUSSE

Institutional Reform in the European

Community: Are there Alternatives to the

Majoritarian Avenue?

RSC No. 95/5

Vivien A. SCHMIDT

The New World Order, Incorporated:

The Rise of Business and the Decline of the Nation-State

RSC No. 95/6

Liesbet HOOGHE

Subnational Mobilisation in the European Union

RSC No. 95/7

Gary MARKS/Liesbet HOOGHE/Kermit BLANK

European Integration and the State
RSC No. 95/8

Sonia LUCARELLI

The International Community and the

Yugoslav Crisis: A Chronology of Events *

RSC No. $95 / 9$

A Constitution for the European Union?

Proceedings of a Conference, 12-13 May 1994,

Organized by the Robert Schuman Centre with the

Patronage of the European Parliament

RSC No. 95/10

Martin RHODES

'Subversive Liberalism': Market Integration, Globalisation and the European Welfare

State

RSC No. 95/11

Joseph H.H. WEILER/ Ulrich HALTERN/ Franz MAYER

European Democracy and its Critique -

Five Uneasy Pieces *

RSC No. 95/12

Richard ROSE/Christian HAERPFER

Democracy and Enlarging the European

Union Eastward

RSC No. 95/13

Donatella DELLA PORTA

Social Movements and the State: Thoughts on the Policing of Protest

RSC No. 95/14

Patrick A. MC CARTHY/Aris

ALEXOPOULOS

Theory Synthesis in IR - Problems \&

Possibilities

RSC No. 95/15

Denise R. OSBORN

Crime and the UK Economy

RSC No. 95/16

Jérôme HENRY/Jens WEIDMANN

The French-German Interest Rate

Differential since German Unification:

The Impact of the 1992-1993 EMS Crises

RSC No. 95/17

Giorgia GIOVANNETTI/Ramon MARIMON

A Monetary Union for a Heterogeneous

Europe 
RSC No. 95/18

Bernhard WINKLER

Towards a Strategic View on EMU -

A Critical Survey

RSC No. 95/19

Joseph H.H. WEILER

The State "über alles"

Demos, Telos and the German Maastricht

Decision

RSC No. 95/20

Marc E. SMYRL

From Regional Policy Communities to

European Networks: Inter-regional

Divergence in the Implementation of EC

Regional Policy in France

RSC No. 95/21

Claus-Dieter EHLERMANN

Increased Differentiation or Stronger

Uniformity

\section{RSC No. $95 / 22$}

Emile NOËL

La conférence intergouvernementale de 1996

Vers un nouvel ordre institutionnel

RSC No. 95/23

Jo SHAW

European Union Legal Studies in Crisis?

Towards a New Dynamic

RSC No. 95/24

Hervé BRIBOSIA

The European Court and National Courts -

Doctrine and Jurisprudence: Legal Change

in its Social Context

Report on Belgium

RSC No. $95 / 25$

Juliane KOKOTT

The European Court and National Courts -

Doctrine and Jurisprudence: Legal Change in its Social Context

Report on Germany

\section{RSC No. 95/26}

Monica CLAES/Bruno DE WITTE

The European Court and National Courts Doctrine and Jurisprudence: Legal Change in its Social Context

Report on the Netherlands
RSC No. $95 / 27$

Karen ALTER

The European Court and National Courts Doctrine and Jurisprudence: Legal Change in its Social Context

Explaining National Court Acceptance of European Court Jurisprudence: A Critical Evaluation of Theories of Legal Integration

RSC No. 95/28

Jens PLÖTNER

The European Court and National Courts Doctrine and Jurisprudence: Legal Change in its Social Context

Report on France

RSC No. 95/29

P.P. CRAIG

The European Court and National Courts Doctrine and Jurisprudence: Legal Change in its Social Context

Report on the United Kingdom

RSC No. 95/30

Francesco P. RUGGERI LADERCHI

The European Court and National Courts Doctrine and Jurisprudence: Legal Change in its Social Context

Report on Italy

RSC No. 95/31

Henri ETIENNE

The European Court and National Courts -

Doctrine and Jurisprudence: Legal Change in its Social Context

Report on Luxembourg

RSC No. 95/32

Philippe A. WEBER-PANARIELLO

The Integration of Matters of Justice and Home Affairs into Title VI of the Treaty on European Union: A Step Towards more Democracy?

RSC No. 95/33

Debra MATIER

Data, Information, Evidence and Rhetoric in the Environmental Policy Process:

The Case of Solid Waste Management

RSC No. 95/34

Michael J. ARTIS

Currency Substitution in European Financial Markets 
RSC No. 95/35

Christopher TAYLOR

Exchange Rate Arrangements for a MultiSpeed Europe

RSC No. 95/36

Iver B. NEUMANN

Collective Identity Formation: Self and

Other in International Relations

RSC No. 95/37

Sonia LUCARELLI

The European Response to the Yugoslav

Crisis: Story of a Two-Level Constraint

RSC No. 95/38

Alec STONE SWEET

Constitutional Dialogues in the European

Community

RSC No. 95/39

Thomas GEHRING

Integrating Integration Theory:

Neofunctionalism and International Regimes

RSC No. 95/40

David COBHAM

The UK's Search for a Monetary Policy:

In and Out of the ERM

\section{米棌}

\section{RSC No. 96/1}

Ute COLLIER

Implementing a Climate Change Strategy in the European Union: Obstacles and

Opportunities

RSC No. $96 / 2$

Jonathan GOLUB

Sovereignty and Subsidiarity in EU

Environmental Policy

RSC No. $96 / 3$

Jonathan GOLUB

State Power and Institutional Influence in European Integration: Lessons from the Packaging Waste Directive 


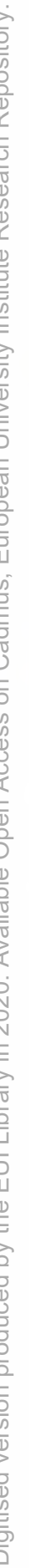


